\title{
The never-ending story of public administration reform in Slovenia (from 1991 to further development)
}

\author{
UDK: 35 (497.12)
}

\section{Polona Kovač}

Fakulteta za upravo, Univerza v Ljubljani polona.kovac@fu.uni-lj.si

\begin{abstract}
In Slovenia, the public administration reform has been a systematic task since 1996 when the government adopted the strategy of transformation of public administration due to Slovenia becoming a full member of EU. Such a strategy could be developed and implemented regarding the fact that Slovenia has had a functioning system of public administration since 1991 when it became an independent state. In the last few years after year 2000 the reform has been built up as constant development of public administration based on several pillars such as civil service system, reorganisation of administrative structures, e-government etc. The public administration reform in Slovenia is therefore aimed at upgrading the existing system in terms of greater professionalism, transparency, efficiency and user-friendly delivery of public services, all together incorporated in the principles of new public management and good governance. The modernisation of Slovene public administration is a process which has been so far based on a rather legalistic approach (a set of basic laws were passed mainly in 2002) and is to be continued especially focusing on process orientation. In July 2003 within special midterm strategy on further development of public sector and later in 2005 within national Strategy on Development of Slovenia till 2013 the coordinated approach has been stressed as well aiming to present administration as an impetus and not an obstacle in developing competitive advantages of national economy. The recommendations that Slovenia can deliver in conducting public administration reform to ensure optimal results are today the following: orientation towards users, effectiveness and efficiency, openness, adequate rewarding of civil servants, optimisation and informatisation of working processes, involvement in international networks, awareness of public administration doings' impacts in national economy, consistent political support, long-term strategic planning.
\end{abstract}

Key words: public administration, reform, Slovenia, EU. 


\section{Polona Kovač \\ The never-ending story of public administration reform in Slovenia}

\section{What is "public administration reform"}

The wording "public administration reform" or "public sector reform" has been commonly used (and abused) worldwide since the end of eighties". There are also some other expressions in use, such as development, modernisation, regulatory reform, lean government etc. Nevertheless all national administrations had the same problems at least till the mid-nineties, most important of all because of the need to cut down the proportion of public expenditure within GDP ${ }^{2}$ and the need for user-oriented public administration. There have been other reasons such as globalisation, privatisation, deregulation, IT development, transition, change of values etc. Primarily the objectives of public administration reforms are increased efficiency and effectiveness ${ }^{\mathbf{3}}$. Some argue that we can recognize the new paradigm called New Public Management, since new approaches are based on the principles of private sector as firstly put forward by Hood $\mathbf{4}^{\mathbf{4}}$. Others stress the meaning of European Administrative Space, developed by SIGMA ${ }^{\mathbf{5}}$ and European Court of Justice with the following guidelines: reliability and predictability, openness and transparency, accountability, efficiency and effectiveness. If we take those principles into account, we would be talking about developing entrepreneurial public administration, which emphasises the value of people involved. Those general frameworks are valid for Slovenia as well, since New Public Management has been officially defined as a governmental current guideline in national strategies from 1996 on.

1 The most famous reforming country is New Zealand, followed by Great Britain, United States of America, Netherlands, Germany, Sweden, France etc. OECD has identified the majority of radical reforms in the period of 1989-1992. In different countries the politiciants and top public managers emphasized different approaches, depending on constitutional and legal system, history, competitiveness of national economy etc. Public administration reforms in Germany are therefore oriented more towards decentralisation and financial management, in USA and GB towards privatisation, users and HRM, in Sweden towards participation and decentralisation (Lane, 1995, Flynn and Strehl, 1996, Peters and Pierre, 2005).

2 In mid-nineties the proportions were 33\% in USA, 43\% in Great Britain, $49 \%$ in Germany, $67 \%$ in Sweden (source: OECD, 1994); in Slovenia from 1992-2005 between 47 and $43 \%$. Ferlie (1996) would say that public expenditure growth is reasonable in the fields of health, education, R\&D, but not in the field of justice, social care and general administration, since this is a clear symptom of no satisfaction in modern society.

3 The well known abbreviation $3 E$ and lately $5 E$ stands for: effectiveness, efficiency, economy and furthermore ethics and environment.

4 The basic seven elements of Chris Hood's findings (1995) about reform in Great Britain are: 1 - orientation towards professional management, 2 - standards and performance measurement, 3 - output control, 4 - decentralisation, 5 - competition, 6 - business methods, 7 economy and efficiency.

5 More: Preparing Public Administrations for the European Administrative Space- EAS (1998) and European Principles for Public Administration (1999), Sigma Papers No 27, OECD, Paris. 


\section{Picture 1: New Public Management}

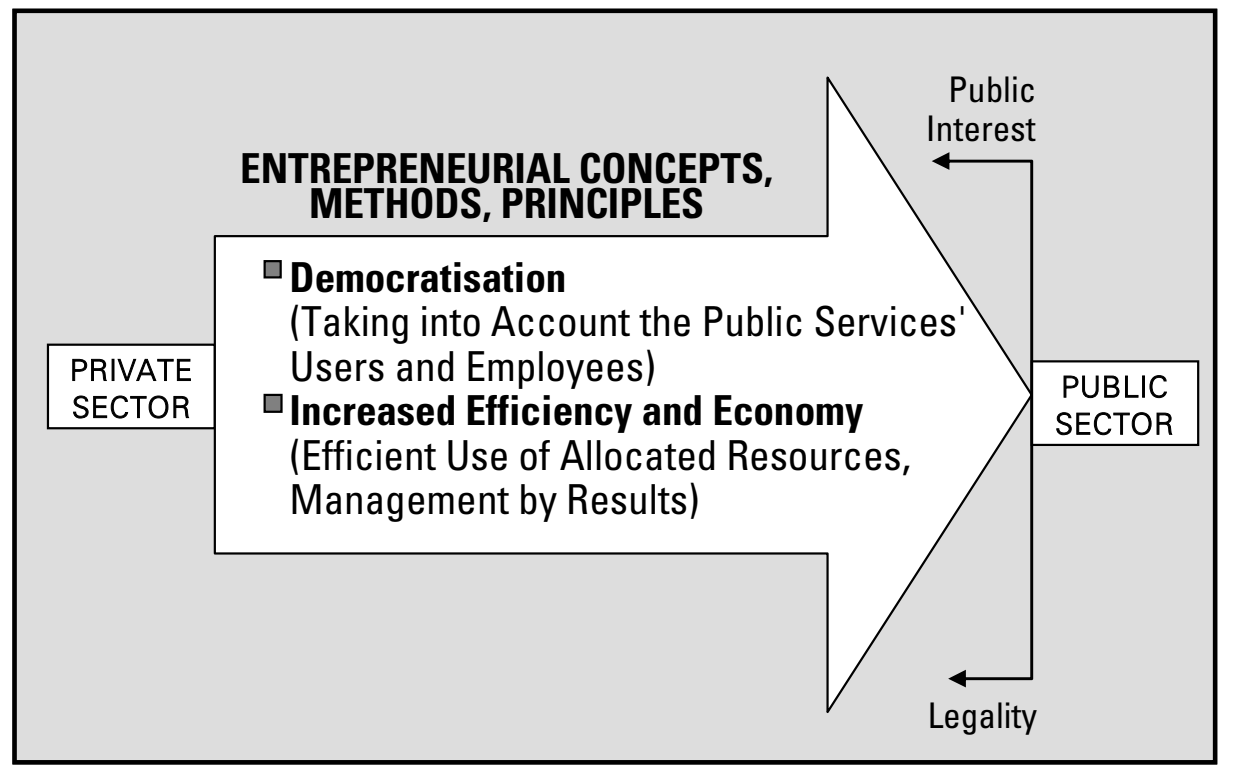

It is worth stressing that Slovenia, as well as other countries of course, had to acknowledge, sometimes even painfully, that the public and the private sector function with different missions, so it is not possible to just "copy\&paste" the private sector methods. The most important drivers to be put in front of efficiency and orientation toward users are therefore legality and public interest, which have to limit entrepreneurial or lately the so-called neoliberalistic approches. The public administration can be oriented toward users, but there are situations when its quality is not satisfying individual interests. Howewer, one must find it hard to define what public interest is in certain cases. But the principles of legality, political neutrality, objectivity, autonomy are nevertheless still more than valid; they are to be upgraded and not replaced by effectiveness and efficiency.

As the grounds for further public administration reforms the philosophy of good governance has been developed in the last few years on the basis of New Public Management within OECD, putting forward not only efficiency, but mainly participative strategic planning by giving the government of the day the crucial role in stimulating cooperation among societal subsystems. Donald J. Johnston, Secretary-General of the OECD, expresses the good governance in the following words: "...the key to providing opportunities for all citizens to enjoy productive and fulfilling lives... is ensuring that the triangular paradigm of economic growth, social cohesion and good governance is kept in balance." 


\section{Polona Kovač \\ The never-ending story of public administration reform in Slovenia}

The principles of good (or some call it corporate or new) governance in Slovenia are emerging in theory (and much slower in practice) from 2003 on, being built in the lately passed Strategy of Development of Slovenia till 2013 (mainly prepared to put forward the priorities Slovenia has to challenge in the first decade of full membership in the EU).

Slovenia has met some major milestones so far by becoming an indepent state in 1991 and joining the EU in 2004. If public administration had not responded to new needs of the state and its people, Slovenia could not have been facing new challenges now, in 2006, such as introducing the euro in 2007 or holding the presidency of the EU in 2008.

Furthermore, public administration is just one pillar creating the public sector system in Slovenia. Namely, in accordance with the Civil Servants Act and the Salary System in the Public Sector Act public sector in Slovenia is regarded as the entirety of government bodies and local self-government units' administrations, public agencies, public funds, public institutes, public economic institutes and other legal persons of public law, when they are classified as national or local communities' budget spending units, all together about 150.000 employees. Public sector therefore covers systems of public education, public health, social welfare, R\&D, judiciary system etc. The public administration is narrower as the entirety of government administration bodies, municipalities' administrations (about 200 of them) and legal persons of public law (public agencies and certain public institutes) performing administrative tasks under public authorisations. There are about 46.000 employees (4\% of active population) working in public administration, about 33.000 of them within state administration (police and army included) and about 4.000 within municipalities. It is worth mentioning that in Slovenia there is a great difference between the state administration (in central and local levels) and local selfgovernment (municipalities). The state administration is represented by 15 ministries and 16 supportive common governmental services, about 50 autonomous units within ministries (such as Tax Office) and 58 local administrative units.

Despite common theoretical dimensions experts identify two major trends of the public sector reforms within the OECD countries: 1- reforms based on privatisation (main goal being free market) and 2- reforms on the basis of de/regulation, but both types aiming to adjust legal framework and the public sector activities to current social environment and joining-up the public and the private sector (Schuppert, 2000, p. 277 and 350). 
We would presume that the basic objectives of public authorities are the following:

1. To protect public interests and therefore regulate those fields where the market would not function in that respect;

2. To plan and control the implementation of public policies;

3. To create an enabling environment to stimulate entrepreneurship and investment (and economic progress and sustainable social development in the long run).

The role of the state is therefore changing - from once being just the institution to remove market dysfunctions to the modern state which acts as a promoter of strategic economic and societal development. The authorities must distinguish whether they are dealing with the power - as an institution and regulative power - or with the services for the people - as an organisation and service provider. When organisation is in question, there is no doubt that efficient public sector is also in the interest of the economy.

\section{Periods of development in slovene public administration}

In Slovenia the public administration reform has been a priority task since 1996 when the government adopted the strategy of transformation of public administration. In the last few years the reform has been built up as a constant development of public administration.

Concerning public administration reform there have been several periods since $1991^{6}$ :

From 1991 to 1996

The turning points in 1991 that triggered a comprehensive reform of public administration were the first democratic elections in Slovenia, its independence in June and the adoption of the Constitution at the end of the same year. Due to a completely new environment in which the Slovenian public administration found itself, the reform was first directed into the establishment of institutions in administrative areas assumed by the Republic of Slovenia from

6 Some recognize the three major periods, as 1- "revolution" (1990-1994), 2- transition (1995-1997) and 3 - accession to the EU (after 1997). 


\section{Polona Kovač \\ The never-ending story of public administration reform in Slovenia}

the former Yugoslavia (defence, customs, citizenship, personal documents etc.), and later into the adjustment of public administration system with the constitutional concept of the division of authority and local self-government (in 1995).

\section{From 1996 to 1999}

Further development of public administration was related to the process of Slovenia's integration into the European Union. In 1996 the government passed the strategy on integration in the EU, including the partial strategy on public administration reform 1997-1999. The basic goals of the strategy were to increase the efficiency of the Slovene public administration and to adjust its functions and structures according to the European standards. The strategy incorporated over 30 projects, joined up into six fields: state administration, local self-government, public utilities, the rights of individuals in administration, civil service system and public finances. The reform was not a success, mostly due to the inconsistent political support and lack of ministerial coordination.

From 1999 to 2003

The periods of 1996-1999 and 1999-2003 have a common denominator: the EU. From 1999 on the basic new laws were prepared and passed later. Within this new context, new legislative framework for public administration had to be developed and harmonized with the standards of the European Administrative Space. Regular reports of the European Commission on the progress of Slovenia in its integration into the European Union $(2002,2003)$ testify that part of the reform was successfully concluded. The reports give positive evaluation of the administrative capacity on both, ministerial and horizontal levels. The legislative part of public administration reform was concluded with the adopting of the six fundamental legal acts: the Civil Servants Act, the Salary System in the Public Sector Act, the State Administration Act, the Inspection Act, the Public Agencies Act and the Act on the Access to Information of Public Character. In 2001, the Government of the Republic of Slovenia began the activities to establish the second level of local self-government and adopted the basis for further development of local self-government, founded in constitutional amendments, in June 2002. In addition to the preparation of a new systemic legislation, numerous measures were implemented in years 2002-2003 on the level of implementing regulations and operative level to improve the quality of public administration operations, its services and information, to attain greater satisfaction of customers and better qualification of employees (e-government, governmental programme on removal of administrative barriers, special training for civil servants in the field of European affairs etc.). 


\section{From 2003 onward}

In July 2003 a special midterm governmental strategy on further development of public sector and in 2005 a broader strategy on development of Slovenia were passed. They define specific objectives and priority activities relating to public administration development in the areas of human resources management, task restructuring and administration organisation, administration and e-government processes, quality management, open administration and public finances. The activities are analytic, implementing and developmental, defining priority tasks, holders and time limits. The strategy from 2003 was the first one to integrate different parts of public administration operations in one document, based on "the vision of the Government of the Republic of Slovenia to shape public administration that shall function under the principles of legality, legal protection and predictability, political neutrality, openness and transparency, quality, effectiveness and efficiency; in which doing, it will obtain results comparable with the result of public administrations in the countries of the European Union, under the indicators of imposed measures and satisfaction of citizens, traders and other affected persons and public-financial effects". Specific measures in the strategies aim to cover pitfalls of reforms so far, such as too legalistic approach to the reform, too much centralisation or on the other hand too much decentralisation without coordination among ministries, lack of political support on the highest level, too many abstract goals without supporting measures etc.

\section{The leading fields and measures in slovene public administration reform}

The legislative part of public administration reform was concluded by implementation of several laws and its secondary legislation from 1997 to 2003:

- the Civil Servants Act (Official Journal of the Republic of Slovenia (OJRS), No 56/02, applied since June 2003),

- the Salary System in the Public Sector Act (OJRS, No 56/02, applied partially since 2004),

- the State Administration Act and the Public Agencies Act (OJRS, No 52/02) and the Inspection Act (Official Journal of the Republic of Slovenia, No 56/02) in force since 2002,

- the Act on the Access to Information of Public Character (OJRS, No 24/03). 


\section{Polona Kovač \\ The never-ending story of public administration reform in Slovenia}

Some of these acts have been newly introduced in every day life and work, so it is too early to evaluate the impacts (3-4 years is not enough to evaluate added value of such umbrella laws, not to mention lack of evaluation criteria set in advance). Nevertheless let us take a look over their objectives and concrete activities. Major emphasis in the Civil Servants Act is given to the renewal of the system of personnel planning and employment, enhancement of the strategic centre for human resources management within administration, decentralisation of human resources management, increasing of internal mobility, planning of employees' career development, optimal use of human resources, separation of political functions from officials' positions, establishment of the top-level public managers, establishment of the Council of Officials representing an independent master of objective selection of the top-level administrative managers, professionalism and stability of administration, a more objective system of selection and remunerations, establishment of the policy of horizontal training and advanced training, and enhancement of social partnership. The Act also introduces the mechanisms for attaining greater flexibility, as well as the rationalisation of operations (project work, reorganisation, temporary and permanent transferral). On the basis of Civil Service Act and State Administration Act the government adopted several decrees in June 2003 to regulate bodies within Ministries, internal organisation, systemisation, positions and the titles within public administration bodies and judicial authorities, internal tendering procedure, as well as restrictions and duties of civil servants related to accepting of gifts. The statistical data have already proven that these measures led to greater efficiency, but regarding the limited influence of politics on civil servants some serious doubts have been introduced, also via Constitutional Court of Slovenia which decided some governmental authorisations on dismissal of top public managers without breaching the law (put in law) to be excessive.

The Salary System in the Public Sector Act (judiciary system included) was adopted in order to establish a uniform salary system in the public sector and ensure a uniform basic salary for comparable positions, motivate and remunerate the above-average work results and effectiveness, ensure the transparency, flexibility and control of the salary system from the point of view of public finance. The Act also stimulates the rationalisation of operations, since it permits that a part of the savings created through rationalisation be directed into the remunerations for employees achieving above-average work results. But the Act itself has not been put in force fully due to some years' negotiation with trade unions regarding collective bargaining, so the goals are still to be reached in practice. 


\section{Polona Kovač \\ The never-ending story of public administration reform in Slovenia}

In the area of training, a special emphasis was given to the implementation of training programmes in the area of European Affairs in accordance with the strategy adopted in 2000. A three-year training programme has been implemented for the elite group of junior officials for the preparation on "concours". In 2003 a special training programme for the highest ranking senior employees ${ }^{7}$ started comprising 8 modules from the areas of administration management, organisation theory, human resources management, strategic planning and decision-making, mastering of changes, relationships and communication, management methods and team work. The training is conducted by Administrative Academy, an internal unit in the Ministry of Public Administration, established in 1997. Academy has so far conducted a lot of programmes, but has not proven itself to be (as planned) a nucleus policy making unit. Instead of preparing annual governmental programmes it focuses only on rather partial execution of certain seminars and exams. Academy will have to take a new role within preparation of Slovenia to organise and lead all activities necessary in the EU during the first half of 2008.

The State Administration Act has, in accordance with the practice of the member states of the European Union, transferred authorisations for the management of the state administration organisation from the parliament to the government, thus ensuring a greater flexibility and minimizing the burdening of the parliament, as well as renovating the management system in state administration (a clearer distinction between political functions and highestranking positions of officials) and regulating more clearly the status of bodies within ministries.

The reorganisation of state administration has not been completed, since it is run on several levels using several legal and other instruments. On macro level there is transition of some state functions into public agencies, institutes and funds. Within state administration the number of governmental services and bodies within ministries need to be rationalised, joined-up, the same goes for local administrative units. Slovene State Administration currently incorporates 15 ministries, about 50 bodies within them such as Police and Inspectorates (10 abolished in January 2004), 16 governmental services (5 abolished in April 2004), 58 (local) administrative units (planning to be centralised in about 14 centres). Decreasing the number of bodies results in fewer direct budget spending units and a greater integration of administration, and thus a less complex coordination, increased political responsibility and a decrease in the number of heads representing the highest-ranking officials' positions.

7 The Decree on Internal Organisation, Job Systematisation, Positions and Titles within Administration and Judicial Bodies (Official Journal of the Republic of Slovenia, No 58/03). 


\section{Polona Kovač \\ The never-ending story of public administration reform in Slovenia}

On mezzo level - within ministries - the new governmental decree in 2003 defined the basis for unified internal structure, building on directorates as basic elements. On micro level there is a reform of civil service system (the systematisations of positions within administration bodies will be essential when shaped as actual, therefore including only the actually employed workers; new/replacement positions, promotions, education and training, departures and others, are covered by the personnel plan of the authority as part of its budget). On the whole there is a demand to consider the type of activities (policy-making, implementation, inspection, public utility etc.), number of employees and procedures/customers and autonomy needed when looking for optimal organisational unit or form. There is, for example, no need to accelerate public agencies without prior analysis of the autonomy needed, growing from internal organisational unit to directorate or autonomous body within the ministry, ministry itself or at least governmental service led by minister portfolio (the latest established at the end of 2005 to carry out the implementation of Strategy on Development of Slovenia) or having an independent public agency or an institute.

The Inspection Act from 2002 provided the legal framework that permits a more efficient and more coordinated work of inspections (enlarged authorisations, establishment of the Inspection Council Coordination, a more adequate procedure regulation). The Public Agencies Act provides for the systemic regulation of a public agency, a so far unregulated status form of the person of public law.

By adopting the act on the access to information of public character the first step was made towards an open administration, classifying Slovenia in the big group of developed countries that are familiar with such legislation (24 of 30 Member States of the OECD). The act allows the citizens to access any information of public character. A procedure is being regulated, under which every individual can acquire any information of public character and which introduces the liability of bodies to actively transfer certain selected information via the World Wide Web. Only confidential information, personal data, professional secrets, etc. are excepted. The access to information of public character is of great importance in the establishment of an overall structure of the open administration: only the citizens that are armed with information will be able to participate in various decision-making procedures and thus effectively realize their right to participate in the adopting of regulations.

The Public Finance Act (Official Journal of the Republic of Slovenia, No 79/99, 110/02) and the Court of Auditors Act (Official Journal of the Republic of Slovenia, No 11/01) were adopted, imposing economical and rational use of budget and other public-financial resources, planning and reporting of the 


\section{Polona Kovač \\ The never-ending story of public administration reform in Slovenia}

direct and indirect national and municipal spending units on obtained goals and results and, consequently, economy audit, as well as audit of the effectiveness and efficiency of operations.

In accordance with ISO 9000 standards almost 30 administration organisations (mostly administration units, but also the government services, one ministry, bodies within Ministries, municipalities) acquired the certificate of quality, respectively. Since 2002, the predominant model (about 60 organisations) in Slovenia, used in accordance with the European trends, has been the European model Common Assessment Framework (CAF) for organisations in the public sector, adapted to public administration and developed on the basis of the concept, model and experience of the European excellence model EFOM, as well as national award for quality like Award of the Republic of Slovenia for Business Excellence.

Amendments to the General Administrative Procedure Act (Official Journal of the Republic of Slovenia, No 52/02) introduced the exchange of information from official databases as a burden of administration and not applicants. A series of measures have been implemented: reengineering of business process, informatisation of registers and providing access to databases (especially the central register of the population and land cadastre), training of employees. Further amendments are being prepared in order to regulate certain unsolved issues of electronic administrative procedure (e-serving, e-submission, e-file). The Administrative Fees Act (May 2002) was also amended. It facilitates the payment of administrative fees by allowing the payment in cash, credit card or other contemporary payment instruments, irrespective of the amount of the fee (implemented since the end of 2003). The Decree on the dealings of public administration bodies with customers (Official Journal of the Republic of Slovenia, No 22/01, 81/03, 20/05) determined minimal standards for dealings with customers. It regulates the obligation to provide information on administration services in different manners, the system of responsiveness to criticism and remarks from customers, the obligatory identification of the satisfaction level of customers, the obligation of the employees to wear identification tags, the discretion field, and others. In February 2003, the portal of administration units was established, representing a sample of a service portal and containing the information on approximately 140 administrative services, structured in a userfriendly manner (the catalogue of life events), however being rather informative and not enabling full communication and back offices optimatisation. The standardized application forms for all types of procedures that are being conducted at administrative units are also available. In 2001 and 2002, the activities of the Government in the area of removal of administrative barriers were directed towards the simplification of procedures for the establishment of 
Polona Kovač

The never-ending story of public

administration reform in Slovenia

companies, influencing the environment and employment of aliens (a summary decision on the fulfilment of conditions for the performance of activity, for the $50 \%$ reduction of court fees, shorter time for company registration, simplified procedures referring to the Spatial Planning Act and the Construction Act, a more rapid acquisition of the residence permit for aliens, partly associated procedures for the acquisition of the residence permit and work permit, new act on nostrification of university degrees and certificates, respectively, acquired in foreign educational institutions and others). The establishment of the Regulatory Impact Analysis (RIA) project (autumn 2002) is of great importance in relation to both, traders and individual citizens.

\section{Further development of slovene public administration/sector}

Further development of Slovene Public administration is inevitably placed within the EU. The EU in general does not include national administration into acquis, when it is capable of implementing the sectoral regulations and directives. Nevertheless some trends are to be followed, especially on the fields of HRM and TQM.

The common critic of public administration reform in mid European space is a too legalistic approach, which is the case in Slovenia as well. It is natural that public administration is accurately defined by legislation to ensure legality, objectivity and the rule of law to avoid misuse. So it is a logical consequence to base the majority of measures on changed regulations, especially those aiming to develop the organisation, functions, civil service system, and management of resources. Nevertheless, initially the legalistic approach should be just one which is later upgraded by process orientation. Within OECD (AngloSaxon legal system) there is even an opposite view: functional analysis should be the starting point to begin restructuring and passing amendments to existing acts and new laws. Both views should be combined to assure optimal effects. Functional studies carried out in 2003 and later have analytically proven the problem of rather isolated reforms so far. Mainly there are strong trends within state administration, but rather poor strive for efficiency for example within municipalities (some even talk of public administration being run in two tracks). There are even more drastic differences among systems

8 Germans have even invented the special word for this phenomenon - Juristenmonopol. Beside officials the citizens as well favour authority, hierarchy and legality to efficiency. 
within the whole of public sector, especially regarding privatisation processes such as those in the area of public health.

As identified in so far conducted partial functional analyses, Slovene public administration should be strengthened from 2006 on basing on four major development problems :

1. quality of regulations,

2. relation to customers and economy,

3. management of resources and its coordination,

4. size and expenditures of state administration or public sector as a whole.

Priority tasks should therefore be connected to ensure optimal results. Some of the key objectives and further tasks to be implemented would be:

- implementing the strategic human resources planning,

- a greater possibility for remunerations according to work effectiveness,

- strengthening the cooperation with civil society and building of partnerships with unions,

- intensive introduction of electronic services in public administration,

- elaboration of methodology for the regulatory impact analysis (RIA).

- expanding and remunerating good practices; developing adequate standards of service quality,

- elaboration of standards for the measurement of efficiency and effectiveness of institutions and individuals, as well as promotion of competition and benchmarking.

To fulfil the goals listed it is of great help to be involved as a state on international level, since it provides additional ideas and checks the state of affairs at home comparatively to international scene. Slovenia is active in international screen for a few years bilaterally (Austria, Germany, GB, Netherlands) and in the context of larger integrations. Slovenia is an active contributor in European Public Administration Network since 2001 (also cooperating fully in 4QC in Tampere in September 2006). Regularly we have cooperated with SIGMA representatives and with European Institute for Public Administration from Maastricht. In February 2003 Slovenia was appointed as an observer in OECD Public Management bodies. Of course some foreign experiences are more and others less applicable, but the process of globalisation should be recognized in the field of public administration as well.

The society and its formal and informal leaders should be aware of economic importance of public sector and administration (framework given by 


\section{Polona Kovač \\ The never-ending story of public administration reform in Slovenia}

Lisbon Strategy). According to assessments, in the last years public sector contributed a good quarter of the added value, while the actual government's impact in the private sector is still great. In addition to the almost complete covering of non-market activities and economic infrastructure, the government can also seize, particularly through national banks and public funds, the potential opportunity to control a greater part of public sector operating under the conditions of competition. Since the response time of the organisations under government control is inevitably longer, both for the reasons of differing legal procedures (for instance, public procurements) as well as for the reasons of potential politisation of strategic decisions, the Government has opted for the minimized ownership role of the government within the private sector, as well as for the continuation of privatisation already in the Strategy of Slovenian Economic Development. The quality of institutional environment is a prerequisite for sustainable economic growth. Some international indicators prove that government is supposed to be active contributor in developing national economy competitiveness ${ }^{9}$. Additionally the size of public sector has to be recognised. The number of employees only in Slovene public administration (now from 33.000 in state administration to about 46.000 all together) has increased three times since 1991 due to the objective reasons (independence, establishment of local self-government, integration in the EU), as well as subjective reasons. The growth of public administration and salaries in public administration (and in the entire public sector) represents an increased pressure on the national budget and one of the reasons for the increase of the publicfinancial deficit. In addition in Slovenia as well as worldwide almost all measures have been taken to assure more user friendly administration and to rationalise it. On the other hand civil servants were rarely systematically motivated and/or awarded at the same time, even though they are the key success factor.

The Government of the Republic of Slovenia realizes that good governance represents one of the pillars of social development and prosperity; the other two being the economic growth and social cohesion. Public administration (should) play(s) a significant role within the framework of good governance, since it provides professional basis for political decision-making and directly enforces the adopted policies. Therefore, the quality of public policies and their

9 To name some: Growth Competitiveness Index - $\mathrm{GCl}$ (its third is represented by Public Institutions Index), Governance Research Indicators Country Snapshot by World Bank (taking into account the quality of governance measuring the quality of regulations, rule of law, efficiency of government, control over corruption), IMF analyses on correlation between GDP per capita and previously mentioned indicators. Only by summary of criteria on government (aggregate governance measure of institutions') almost three quarters of differences among GDP per capita can be explained (IMF, World Economic Outlook, April 2003). 
actual social value depend to a large extent on the quality, effectiveness and success of its operating.

Slovenia has declared the goals mentioned, but implementation is rather poor especially regarding public-private partnerships in all forms (institutional, contractual and other arrangements, formed between a public agency and a private company that can include a variety of activities that involves the private company in the development, financing, ownership and/or operation of a public facility or service). Public sector and public/state administration still seem to be self-efficient. Reasons for the development of PPP could be grouped as economic (budgetary and entrepreneurial) and social reasons; the first ones further more classified into macroeconomic, dealing with availability of public investments, and secondly microeconomic, dealing with efficiency of public expenditure. Public private partnerships can offer innovative and competitive solutions when value for money is demonstrated, risk is allocated to the partner best able to manage and mitigate it and processes are open, fair and transparent. On the other hand there are some disadvantages. The most important one is connected to competition or in fact with the lack of it. Privatisation and PPP are in the function of growing efficiency and quality as far as there is significant number of potential suppliers of public services. Therefore, some favouring circumstances or even conditions for a successful PPP are regulatory framework ensuring fair procedure, existing programmes of investments, risk management, relatively balanced social, economic, technical and institutional environment etc., which Slovenia still lacks.

Let us conclude by emphasizing once again the great importance of government provided consistent political support and pro-active stand. It takes time to modernise public administration, since public administration reform means the change of the mentality. As public administration is functioning within rapidly changing societal environment, public administration reform is, as we all know and hope for, the never-ending story. 


\section{Polona Kovač \\ The never-ending story of public administration reform in Slovenia}

Dr. Polona Kovač je višja predavateljica na Fakulteti za upravo Univerze v Ljubljani. Doktorirala je I. 2005 na Pravni fakulteti v Ljubljani. Prednostno se ukvarja z upravnimi postopki (splošni upravni postopek, davčni postopek, uveljavljanje pravic iz socialnih zavarovanj, inšpekcijski nadzor idr.) in nasploh s pravno ureditvijo javne uprave. Poleg tega je dejavna na področju kakovosti, zlasti rabe modelov odličnosti v javnem sektorju. S slednjim se ukvarja od I. 2001, od tega do I. 2004 kot nacionalna koordinatorica za uvajanje modela CAF v slovensko upravo, od I. 2005 dalje pa kot razsodnica v postopku Priznanja RS za poslovno odličnost. Redno objavlja $v$ strokovni literaturi in sodeluje na domačih in tujih konferencah. Je izvajalka vrste seminarjev in delavnic na področju kakovosti in pravne ureditve javne uprave, od I. 2005 je tudi predstojnica za izobraževanje javnih uslužbencev na Fakulteti za upravo. Raziskovalno vodi in je udeležena $v$ različnih skupinah, tudi $v$ mednarodnem projektu Evropske komisije One Stop Government (6. okvirni raziskovalni program).

\section{Literatura in viri}

- Engel, C.(2003): Quality Management Tools in CEE Candidate Countries - Current Practice, Needs and Expectations, European Institute of Public Administration, Maastricht.

- European Institute of Public Administration, http://www.eipa.nl/default.htm/Projects/CAF.

- European Principles for Public Administration, (1999), Sigma Papers No. 27, OECD, Paris.

- Flynn, N. and Strehl, F.(ed.)(1996): Public Sector Management in Europe, Prentice Hall,.

- Hood, C. (1996): Contemporary Public Management: a New Global Paradigm, Public Policy and Administration, Volume 10, No. 2, 104-117.

- Kovač, P. (2003): Evropski upravni prostor - realnost ali mit, Uprava, Nr. 2, Fakulteta za upravo, Ljubljana.

- Lane, J. E.(1995): The Public Sector, Sage Publications, London, Thousand Oaks, New Delhi,.

- $\quad$ OECD Principles of Corporate Governance, (2004) http://www.oecd.org/dataoecd/32/18/31557724.pdf.

- Peters, B. G., Pierre, J. (ed.)(2005): The Handbook of Public Administration, SAGE Publications, London, Thousand Oaks, New Delhi. 
The never-ending story of public administration reform in Slovenia

- Pollitt, C., Talbot, C. (ed.)(2004): Unbundled Government, A critical analysis of the global trend to agencies, quangos and contractualisation, Routledge, London and New York.

- Strategija nadaljnjega razvoja slovenskega javnega sektorja 2003-2005, Vlada Republike Slovenije, (2003), http://www.mnz.si/si/14.php.

- Strategija RS za vključitev Slovenije v Evropsko unijo, Poročevalec Državnega zbora Republike Slovenije, 48/97 in 48/I/97, 1996, 61-73 and 168-207.

- $\quad$ Schuppert, G. F. (2000): Verwaltungswissenschaft. Nomos, Baden-Baden.

- Trpin, G. (2003): Nove možnosti organiziranja javne uprave in učinkovitost upravnih sistemov, Uprava, Nr. 2, Fakulteta za upravo, Ljubljana. 
Polona Kovač

The never-ending story of public

administration reform in Slovenia

\section{POVZETEK}

\section{Reforma slovenske javne uprave (od 1991 k nadaljnjemu razvoju) kot nikoli končana zgodba}

Pojem "upravne reforme" se je začel v svetu uveljavljati konec osemdesetih in $v$ začetku devetdesetih let prejšnjega stoletja. Temeljiti prenovi vladnega sektorja je $\vee$ posameznih državah, tudi v Sloveniji, botrovalo več vzrokov, med katerimi je treba izpostaviti potrebo po zmanjšanju deleža javne porabe $v$ bruto domačem produktu ter uveljavljanju glasu uporabnikov javnih storitev in javnih uslužbencev. Reforma slovenske javne uprave se pojavlja kot prioritetna vladna politika od sredine devetdesetih let dalje, zlasti $v$ povezavi s procesom vključevanja Republike Slovenije $v$ Evropsko unijo. Posamični sodobni pristopi so bili zaznavni že prej, ko se je slovenska uprava pravzaprav šele oblikovala, vendar o (bolj ali manj) sistematičnem načinu nadgrajevanja dela govorimo po letu 1997. V grobem ločimo štiri obdobja modernizacije in razvoja slovenske javne uprave: (1) med leti 1991 in 1996, ko se je Slovenija kot država osamosvojila in radikalno prenovila sistem državen uprave in ločene lokalne samouprave, (2) med leti 1996-1999, ko je Slovenija delovala v skladu s strateškim načrtom za uvedbo reforme slovenske javne uprave 1997-1999 kot delu strategije RS za vključitev v EU, (3) med leti 2000-2003, ko je bila glavnina reforme usmerjena $v$ zakonodajne projekte, in (4) po letu 2003, ko se reforma pojmuje kot stalen program s konkretnimi časovno opredeljenimi projekti, pri čemer modernizacija javne uprave temelji na strateških dokumentih, kot je zlasti Strategija razvoja Slovenije do leta 2013 (za prvih deset let članstva v EU).

$\checkmark$ razvojnem procesu je medsebojno povezanih več dimenzij spreminjanja uprave - funkcionalna, organizacijska, upravljavska (glede kadrov, financ, IT idr.), procesna dimenzija. Slovenska uprava je bila reformirana predvsem glede organizacijskih struktur in načinov upravljanja virov, medtem ko procesni vidik ni bil v ospredju. To ni presenetljivo, če si predočimo dejstvo, da uprava deluje kot monopolna dejavnost $\mathrm{s}$ ciljem varovanja javnega interesa. Da bi preprečili zlorabo oblasti je zato zanjo značilna velika stopnja regulacije. Posledično je tudi reforma uprave - vsaj $\checkmark$ delu, ki določa njene naloge in strukturo - nujno predvsem normativnega značaja. $Z$ vidika normativne podobe reforme slovenske uprave so najpomembnejši $v$ maju in juniju 2002 sprejeti t. i. sistemski zakoni, uveljavljeni pa so bili nekateri šele par let kasneje. To so v prvi vrsti Zakon o 
državni upravi, Zakon o javnih agencijah, Zakon o javnih uslužbencih, Zakon o sistemu plač v javnem sektorju, Zakon o inšpekcijskem nadzoru, Zakon o splošnem upravnem postopku z novelami, Zakon o javnih financah, Zakon o javnih skladih, Zakon o lokalni samoupravi z novelami in povezanimi predpisi in drugi. $\mathrm{V}$ bistvu gre pri določbah teh zakonov za redefinicijo pristojnosti in racionalizacijo strukture uprave, tako da sta zaokroženo opredeljena temeljna strukturna dela uprave, kot jih definira OECD: najprej neposredna uprava pod direktnim hierarhičnim nadzorom vlade, in nadalje posredna uprava, ki vključuje organizacije s samostojno pravno subjektiviteto, kot so samostojne javne agencije (regulatorne in druge, kar je od leta 2002 nova sistemsko urejena statusna oblika oseb javnega prava $v$ slovenskem pravnem redu), javni zavodi, javni skladi itd. Glavni poudarki uvedbe uslužbenskega sistema v letu 2003 pa so: prenova sistema kadrovskega načrtovanja in zaposlovanja, decentralizacija upravljanja kadrovskih virov, povečanje interne mobilnosti, optimalna izraba kadrovskih virov, oblikovanje ravni vrhunskih javnih menedžerjev, profesionalizacija in stabilnost uprave, objektivnejši sistem izbire in nagrajevanja, vzpostavitev politike horizontalnega usposabljanja in izpopolnjevanja, mehanizmi za doseganje večje fleksibilnosti in za racionalizacijo poslovanja (projektno delo, reorganizacija, premestitev), socialno partnerstvo idr.

Med pomembnimi programi, ki so predmet reforme slovenske javne uprave, pa kaže omeniti tudi od leta 2001 dalje vzpostavljeni program odprave administrativnih ovir. Od leta 1996 se v slovenski upravi nadalje vse več organizacij odloča za upravljanje kakovosti v lastnih organih tudi s pomočjo standardov in modelov kakovosti /odličnosti. Med standardi je najpogostejši ISO 9001:2000 (certifikat je bil do leta 2003 pridobljen v približno 30 slovenskih upravnih organih). Evropski Skupni ocenjevalni okvir za organizacije $v$ javnem sektorju - CAF (angl. Common Assessment Framework), ki temelji na modelu odličnosti EFQM, se uporablja v Sloveniji od leta 2002 dalje. Do sedaj ga je uporabilo približno 80 slovenskih upravnih organov. Na centralni ravni je za področje upravljanja kakovosti ključna Uredba o upravnem poslovanju (sprejeta leta 2005), ki pomeni nabor minimalnih standardov med upravo in strankami (npr. posredovanje splošnih informacij, ugotavljanje zadovoljstva strank, obvestila o poteku postopkov, knjiga pripomb in pohval, označbe prostorov in identifikacijske značke, črta diskretnosti).

Kritike reforme slovenske uprave se večinoma nanašajo na posamezne sklope pristopov, bodisi $v$ zvezi $z$ določenim zakonom ali področjem 
Polona Kovač

The never-ending story of public

administration reform in Slovenia

(npr. e-uprava). Med najbolj pogostimi očitki je vsekakor (pre)velika naravnanost reforme na regulativo. Nadalje se večkrat navaja, da je reforma kot vseobsežna javna politika premalo sistematična. Temu botruje nenazadnje deljena odgovornost nosilcev posameznih delov reforme. Vsebinski problem pa je mestoma kar konceptualna neusklajenost ciljev in pristopov posameznih politik oz. aktov. Dodatno zlasti davkoplačevalci slovenski javni upravi očitajo njeno preobilnost, stalno naraščanje števila javnih uslužbencev. Končno je treba izpostaviti, da je lahko modernizacija uprave uspešna le ob stalni politični podpori, katere konsistentnost v zadnjih letih ni bila vzorna (npr. glede racionalizacije upravnih struktur).

Modernizacija javne uprave je proces, ki je do sedaj pretežno temeljil na legalističnem načelu (pretežni del sistemske zakonodaje je bil na novo sprejet $v$ letu 2002), torej veri, da se reforma izvede le s spremembo zakonodaje. Reforme so izhajale prednostno iz spremembe struktur, namesto procesov in šele posledično organizacije in funkcionalne porazdelitev nalog. Strategija razvoja Slovenije do leta 2013 pa pojmuje modernizacijo javne prave kot stalen program, ki ga sestavlja kopica ukrepov, pri čemer strategija izhaja iz pojmovanja upravnega sistema kot spodbujevalca in ne ovire pri razvoju konkurenčnosti nacionalnega in širše evropskega gospodarstva. Ključni razvojni problemi slovenske javne uprave, na katerih je treba graditi, so tako: kakovost regulacije in koordinacija razvojnih politik, odnos do uporabnikov, zlasti gospodarskih subjektov, način upravljanja kadrovskih, finančnih, informacijskih in drugih virov, krčenje in decentralizacija uprave. $V$ tem smislu naj bi bil nadaljnji razvoj javne uprave osnovan na naslednjih načelih oz. ciljih: usmerjenost k uporabnikom javnih storitev, uspešnost in učinkovitost, odprtost in preglednost, ustrezno nagrajevanje javnih uslužbencev, optimizacija in informatizacija delovnih procesov, vključenost $v$ mednarodne navezave, zavest o vplivu delovanja javne uprave na nacionalno ekonomijo, stalna politična podpora in dolgoročno strateško načrtovanje. Zaradi potrebe po gospodarni rabi virov, je treba le-te uporabiti $v$ skladu $z$ vnaprej opredeljenimi in ponderiranimi cilji uprave kot celote. Izpostaviti je treba pomen javnih uslužbencev, saj je uspešna tista organizacija, ki gradi na sposobnosti in motiviranosti ljudi. Zaradi hitrega napredka je na področju informatizacije priložnosti za modernizacijo največ, najteže - a neizogibno - pa bo streti oreh gospodarne in manj ekstenzivne porabe javnih financ. Sodobna uprava mora biti vitka, torej okleščena nepotrebnih administrativnih opravil, ki obremenjujejo tako stranke kot institucije same. Država oz. občina si mora pridržati določitev javnih dobrin in storitev, torej oblikovanje javnih politik in nadzor nad njihovim izvajanjem, medtem ko se sama eksekutiva postopoma prenaša v širši javni sektor oz. zasebni sektor. 